they most concern, we take leave with regret of one of the most attractive little volumes on birds it has been our fortune to peruse.

Of a very different type is the work standing second on our list, although here, too, we have to call attention to some excellent illustrations of the environment of particular species of birds. Apart from the classified list of species frequenting Rhode lsland, the leading idea in Messrs. Howe and Sturtevant's little volume seems to be the peculiar nature of bird nigration in this district, much of which takes place to seaward of the island itself. Especially interesting are certain local migratory move. ments, both along the coast and in Narragansett Bay; foremost among which is the westward migration of white-winged Scoters in May. These birds winter in the neighbourhood of Cape Cod, and during their spring migration fly west, it is said in millions, across Rhode Island, and then shape their course in a north-westerly direction for the great lakes, where they breed.

Following a list of the nesting times of the various species breeding on the island, the authors give an interesting account of "Cormorant Rock," which appears to be the favourite bird-haunt. This is followed by the detailed list of species; the special interest of which can be best appreciated by local observers and students of geographical distribution. In reference to the description of "Cormorant Rock," we may point out to the authors that it is somewhat redundant to speak of the "Island of Rhode Island "; and that the "mesa top of the rock" is a phrase of which the meaning is not quite as apparent as it might be.

Of the third nember of the trilogy we cannot at pre sent speak very fully, since the part before us appears to be only a small instalment of what promises to be a vork of some size and importance. Mr. Cory is already well known to bird-lovers by several works devoted to the avifauna of North America and the West Indies; while to the sportsman his name is familiar as the author of "Hunting and Fishing in Florida."

In the present work it appears to be his object to teach the beginner the external anatomy of a bird (if such an expression be permissible), and then to lead him on to learn how to distinguish and recognise the various kinds of "water birds" found in eastern North America. Although using the latter term in a very wide sense, and including under it such diverse forms as Auks, Gulls, Ducks, Herons, and Snipe, his "keys" appear to be carefully drawn up, and to suffice for the identification by an artificial method of the various species inhabiting the area of which the work treats. The illustrations, although some are on an unduly small scale, are for the most part of a high grade of excellence, and serve to elucidate the technical matter of the text. It is, however, distinctly a subject for regret that the author has seen fit to multiply in a most unnecesssary degree the number of "families" of water birds. He divides the Limicola, for instance, into the Phalaropodidae, Recurvi rostridae, Scolopacidae, Charadriidae, Aphrizidae, and Haematopodidae, whereas in the British Museum Catalogue the whole of these are included in a single family. Moreover, if such divisions were necessary the term Himantopodidae should have been employed, instead of Recurvirostridae, for the Stilts and Avocets.

Neither is the author quite happy in some of the statements in the Introduction, as, for example, when he speaks of the extinct New Zealand Eagle (Harpagornis) as being the prototype of the "Roc of nursery lore." In all probability the honour of that position belongs to the extinct Malagasy Epyornis, and most assuredly the legend does not owe its origin to the "nursery."

On the whole, however, the work, so far as we can judge at present, appears well adapted for its purpose, and we shall look forward with interest to its completion.

R. L.

\section{THE LONDON UNIVERSITY ELECTION.}

$\mathrm{F}$ VERY graduate of the University of London who has the advancement of learning and the best interests of his University at heart, will give careful consideration to the address which has been drawn up by Sir Michael Foster's Election Committee, and the accompanying letter from Sir Michael Foster himself. These two documents should completely remove the impression that the return of Sir Michael Foster would mean the neglect of the rights and privileges of private students. The position of such students and the system of open examination for them have already been definitely settled by Parliament, and it is improbable that any change will be made no matter which candidate is elected. It is therefore not reasonable to think that the electors will let this question influence their votes. Sir Michael Foster stands both for external and internal students, and not for any particular party or as the champion of any one section of the graduates. As a man of distinguished eminence, who has shown his regard for the welfare of the University, we claim for him the suffrages of an intellectual electorate. By returning him to Parliament, not only will the progress of the University be secured, and a member be obtained whose best energies will be used to further the interests of all branches of learning, but the existence of a University representative will be justified.

The following correspondence has been sent to the electors :-

$$
\begin{gathered}
\text { I, New Court, Carey Street, } \\
\text { Lincoln's Inn, London, }
\end{gathered}
$$$$
\text { January 26, } 1900 .
$$

Sir, - It will soon be the duty of the Members of the Convocation of the University of London to choose a representative in Parliament in the place of Sir John Lubbock.

It is now generally admitted that University constituencies should send to Parliament men distinguished in learning. science, or literature, and qualified therefore to strengthen the Legislature in dealing with those questions which inost nearly concern the intellectual interests of the community. This has been recognised of late years in the election of Sir George Stokes, Prof. Jebb, Mr. Lecky and Sir William Anson, in which cases the example set by the University of London in its election of Mr. Lowe and Sir John Lubbock was followed by the older Universities. We hope that the graduates will not now depart from the precedent set on those occasions.

At the present time, when the reconstruction of the University is imminent, it is most important that the representative selected should be a graduate of the highest literary or scientific distinction, able to speak with authority on matters connected with education or research. The new duties which the University will have to undertake must raise questions on which the Government and Parliament will look to the representative of the University for guidance; while the graduates will desire that the claims of the University shall be adequately supported by their member.

So far as the domestic policy of the University is concerned, it should be borne in mind that this is now definitely and permanently settled by the Act of Parliament of last Session, which provides guarantees for the maintenance, in unimpaired efficiency, of the system of open examination for external students. No interference with this settlement on the part of the Legislature or the Government is to be expected or will be required.

Sir Michael Foster, K.C.B., M. D. (Lond.), Senior Secretary of the Royal Society, and now President of the British Association, has, at our earnest request, consented to be nominat ed for the vacant seat. He holds, in the estimation of the public, as well as in that of scientific men, such a distinguished position-not only among the graduates of the University, but an:ong the leaders of scientific thought in Europe-that it is altogether unnecessary for us to dwell on his qualifications in this respect. We may say, however, without fear of contradiction, that there is no one whose opinion on questions affecting scientific education and research or the study of medicine would have greater weight in the House of Commons. His long academical ex perience, first at University College, London, and subsequently at Cambridge, together with his full knowledge of University 
questions, will enable him to be of the greatest service in Parliament. The election of so distinguished a graduate will be an honour to the University.

Sir Michael Foster's claims to your support are not put before you in the interest of any political party. We think it more important that a fit representative of the University, as an institution for the promotion of learning and science, should be sent to Parliament, than that a member should be added to one or the other side of the House. There is, however, one question upon which the country, independent of party, is agreed - that the Government must be supported in prosecuting the present war to a successful conclusion-and on this Sir Michael Foster is at one with the country.

It is of the utmost importance that those graduates who will support Sir Michael Foster should inform the committee at once, and you will please therefore fill up, sign, and post the enclosed card as soon as possible.

We enclose with this a letter from Sir Michael Foster.

$$
\text { We are, Sir, }
$$

Your obedient servants

I. F. Rotron, M.A., LL.B., Q.C., Chairman.

II. J. WARING, M.S., M. B., B.Sc.,

$\left.\begin{array}{l}\text { II. J. Harris, B.A., } \\ \text { C. E. Wilson, M.A. (Camb.), B.A. (Lond.), }\end{array}\right\}$ Secretaries.

The following lelter has been received from SIR MICHAEL FOSTER in answer to one from the Chairman of his Committee informing him of the steps which were being taken in respect of his candidlature.

January 24, 1900.

My Dear RotTon,--I learn from your letter, and from other sources, that the Members of Convocation on whose behalf you write have been led to invite me to represent them in Parliament because they strongly hold the opinion that the representative of the University should be chosen not on account of his political opinions, but by reason of his fitness to advance in the House of Commons the interests of science and learning and of the University, and because they think that I possess this fitness.

I cannot but be gratified that so many eminent graduates hold me in so much esteem ; and, while not so confident myself as they are of my fitness for the post, I feel it my duty to accept the great honour which they offer me in the spirit in which it is proposed.

If my candidature should prove in the end acceptable to the majority of the Members of Convocation, I shall feel that I enter the House, not with a mandate to support this or that political party, but for the purpose of placing at the disposal of the House the experience gained by many years' service in the courts of learning and science, and in more than one University.

Any other position would be impossible for me; and if the Members of Convocation do me the honour to select me, it must be on the understanding that I am not thereby pledged to any political party. Still, the man in the lecture room, no less than the "man in the street," has his political views; and neither would the University expect its Member to take part in the business of the House only when academic questions were being dealt with, nor should I desire to play such a part. Indeed, purely political questions may be brought forward on which, were I elected, I should think it wrong to abstain from recording my vote. Bearing this in mind, I think it right to say that had I been in the House of Commons some years ago, I should have voted against the Irish policy of Mr. Gladstone ; and that at the present moment I think, not only that the present war should be vigorously prosecuted until the results so essential to the welfare of the Empire are attained, but that the nation is justified in having entered into it. So far I should support the present Government. At the same time I wish to state plainly that on many other questions my views, and perhaps still more my sympathies, are those which used to be denoted by the term "liberal." Not having, however, looked forward to the honour of entering into Parliament I have never attempted to integrate my opinions into a compact whole capable of being marked with a party sign; and even now I feel a great difficulty in attempting to do so.

As regards the affairs of the University of London itself, Members of Convocation are well aware that such efforts as have been able to make have been directed towards developing the University in the direction which has often been denoted by the words "teaching University." In this I have been guided by a desire to promote the interests, not so much of teachers, as of teaching and of learning. Though a somewhat long experience as an exaninee and an examiner has shown me the weak points of examinations, I owe too much to the University of London in its old form as an examining University not to feel deeply how much gnod it has done. When called upon as a witness before the Cowper Commission, the only evidence I ventured to give was to emphasise the desirability of enlarging the old University, as against setting up a new one. I thought then, and I think now, that the changes which it is proposed to make, so far from doing any one part of the University harm, will do good to the whole; and that he whom it is proposed to call an "external student" will share, with the "internal student," the benefit which must follow upon the recognition of the principle that the true function of a University, whatever else it may be called upon to do, is not to grant titles, but to develop learning and to promote the advancement and spread of knowledge. If elected, I should regard myself as the representative of the educational interests of external students and internal students alike. Yours. \&c.

Michael Foster.

\section{PROFESSOR D. E. HUGHES, F.R.S.}

DAVID EIWWARD HUGHES was born in London on May I6, I83 I. His parents were Welsh, from Bala, in Merionethshire. $\mathrm{He}$ spent his early years in the United States, to which place his parents emigrated in 1838 , and he became a citizen of the United States. He never abandoned this citizenship, and this is probably the reason why the English Government never recog. nised his eminent scientific services. Being a musician, like so many of those who spring from our Welsh hills, he was appointed professor of music in Bardstown, Kentucky, at the age of nineteen. He also held the chair of natural philosophy. At the age of twenty-four he invented his celebrated Roman type-printing telegraph that spread his fame throughout the civilised world. He struck a new line. His instrument was beed on synchronism, and each letter was struck by one current His apparatus was adopted in the United States, but it was very little used there, and he came to England in I857. to try and introduce it here. He came at an unfortunate time. Telegraphy was in the hands of several private companies, whose capital was locked up in promoting other patents. Competition was excessive and ruinous; but in 1863 the United Kingdom Telegraph Co. took up Hughes's instrument, and on the transference of the telegraph to the State, in 1870 , it came into the possession of the Post Office. It was also employed by the Submarine Telegraph Co. for their communications to the Continent, and now the largest Hughes's typeprinting telegraph station in the world is probably the cable room of the Post Office in St. Martin's le Grand. In his occasional visits to the General Post Office he never failed to express his delight at the great advances made by the Post Office Technical Staff in the development and working of his beloved child. It was driven electrically, and it worked duplex.

Hughes's instrument was made the international type of apparatus, and every country in Europe adopted it. Honours and wealth were showered on him. Being a man of very simple habits and of few wants, his annual expenditure was small; but his income was great. His riches accumulated, and it is now generally known that he has been most generous in endowing various scientific institutions and hospitals with large sums of money.

On April 13, 1859, a paper was read before the Society of Arts describing not only his apparatus, but an original form of cable, which separated two layers of gutta-percha insulation by a film of semi-fluid viscid oil, so that flaws or punctures in the insulation were automically repaired.

NO. I 579 , VOL. 6 i] 